\title{
Matematika dengan Menerapkan Metode Pemberian Balikan Pada Siswa Kelas VI SD
}

\author{
Suratman \\ Guru SDN 2 Penjangka, suratman@gmail.com
}

\begin{tabular}{l} 
INFO ARTIKEL \\
\hline Riwayat Artikel: \\
Diterima: $24-02-2018$ \\
Disetujui: $21-03-2018$ \\
\end{tabular}

Kata Kunci:

Efektif,

Pemberian Balikan,

Matematika

\begin{abstract}
ABSTRAK
Abstrak Tujuan penelitian ini adalah untuk mengungkap keffektifan pembelajaran dengan pemberian balikan terhadap hasil belajar Matematika tehadap siswa kelas IV SDN 2 Penjangka menggunakan penelitian tindakan (action research) tiga siklus. Metode Pengumpulan Data tes formatif, observasi kegiatan belajar mengajar, dan dokumentasi. Didapatkan bahwa prestasi belajar siswa mengalami peningkatan dari siklus I sampai siklus III yaitu, siklus I (69,44\%), siklus II (80,56\%), siklus III (88,89\%). Disimpulkan bahwa pembelajaran dengan pemberian balikan efektif meningkatkan prestasi belajar Siswa SDN 2 Penjangka, sehingga model pembelajaran ini dapat digunakan sebagai salah satu alternatif pembelajaran matematika.
\end{abstract}

\begin{abstract}
The purpose of this study is to reveal the effectiveness of learning by giving feedback to learning outcomes Mathematics to fourth grade students SDN 2 Penjangka using action research (action research) three cycles. Methods Data Collection formative tests, observation of teaching and learning activities, and documentation. It was found that students' learning achievement improved from cycle I to cycle III that is, cycle I $(69,44 \%)$, cycle II (80,56\%), cycle III (88,89\%). It was concluded that learning with effective reversal improves student achievement of SDN 2 Penjangka, so this learning model can be used as an alternative to mathematics learning.
\end{abstract}

\section{A. LATAR BELAKANG}

Tugas utama guru adalah bertanggung jawab membantu anak didik dalam hal belajar. Dalam proses belajar mengajar, gurulah yang menyampaikan pelajaran, memecahkan masalahmasalah yang terjadi dalam kelas, membuat evaluasi belajar siswa, baik sebelum, sedang maupun sesudah pelajaran berlangsung (Combs, 1984:11-13). Untuk memainkan peranan dan melaksanakan tugas-tugas itu, seorang guru diharapkan memiliki kemampuan professional yang tinggi. Dalam hubungan ini maka untuk mengenal siswa-siswanya dengan baik, guru perlu memiliki kemampuan untuk melakukan diagnosis serta mengenal dengan baik cara-cara yang paling efektif untuk membantu siswa tumbuh sesuai dengan potensinya masing-masing.

Dengan tercapainya tujuan dan kualitas pembelajaran, maka dikatakan bahwa guru telah berhasil dalam mengajar. Keberhasilan kegiatan belajar mengajar tentu saja diketahui setelah diadakan evalusi dengan berbagai faktor yang sesuai dengan rumusan beberapa tujuan pembelajaran. Sejauh mana tingkat keberhasilan belajar mengajar, dapat dilihat dari daya serap anak didik dan persentase keberhasilan anak didik dalam mencapai tujuan pembelajaran khusus. Jika hanya tujuh puluh lima persen atau lebih dari jumlah anak didik yang mengikuti proses belajar mengajar mencapai taraf keberhasilan kurang (di bawah taraf minimal), maka proses belajar mengajar berikutnya hendaknya ditinjau kembali.

Setiap akan mengajar, guru perlu membuat persiapan mengajar dalam rangka melaksanakan sebagian dari rencana bulanan dan rencana tahunan. Dalam perisiapan itu sudah terkandung tentang, tujuan mengajar, pokok yang akan diajarkan, metode mengajar, bahan pelajaran, alat peraga dan teknik evaluasi yang digunakan. Karena itu setiap guru harus memahami benar tentang tujuan mengajar, secara khusus memilih dan menentukan metode mengajar sesuai dengan tujuan yang hendak dicapai, cara memilih, menentukan dan menggunakan alat peraga, cara membuat tes dan menggunakannya, dan pengetahuan tentang alat-alat evaluasi.

Sementara itu teknologi pembelajaran adalah salah satu dari aspek tersebut yang cenderung diabaikan oleh beberapa pelaku pendidikan, terutama bagi mereka yang menganggap bahwa sumber daya manusia pendidikan, sarana dan prasarana pendidikanlah yang terpenting. Padahal kalau dikaji lebih lanjut, setiap pembelajaran pada semua tingkat pendidikan baik formal maupun non formal, haruslah berpusat pada kebutuhan 
perkembangan anak sebagai calon individu yang unik, sebagai makhluk sosial, dan sebagai calon manusia seutuhnya.

Hal tersebut dapat dicapai apabila dalam aktivitas belajar mengajar, guru senantiasa memanfaatkan teknologi pembelajaran yang mengacu pada pembelajaran dengan pemberian balikan dalam penyampaian materi dan mudah diserap peserta didik atau siswa berbeda.

Khususnya dalam pembelajaran matematika, agar siswa dapat memahami materi yang disampaikan guru dengan baik, maka proses pembelajaran dengan pemberian balikan, guru akan memulai membuka pelajaran dengan menyampaikan kata kunci, tujuan yang ingin dicapai, baru memaparkan isi dan diakhiri dengan memberikan soal-soal kepada siswa.

Dari latar belakang masalah tersebut, maka perlu dilakukan penelitian "Meningkatkan Motivasi dan Prestasi Belajar Matematika dengan Menerapkan Metode Pemberian Balikan Pada Siswa Kelas VI SDN 2 Penjangka".

\section{B. METODE PENELITIAN}

Penelitian ini mengacu pada perbaikan pembelajaran yang berkesinambungan. Kemmis dan Taggart (1988:14) menyatakan bahwa model penelitian tindakan adalah berbentuk spiral. Tahapan penelitian tindakan pada suatu siklus meliputi perencanaan atau pelaksanaan observasi dan refleksi. Siklus ini berlanjut dan akan dihentikan jika sesuai dengan kebutuhan dan dirasa sudah cukup.

\section{Rancangan Penelitian}

Sesuai dengan jenis penelitian yang dipilih, yaitu penelitian tindakan, maka penelitian ini menggunakan model penelitian tindakan dari Kemmis dan Taggart (1988:14), yaitu berbentuk spiral dari siklus yang satu ke siklus yang berikutnya. Setiap siklus meliputi planning (rencana), action (tindakan), observation (pengamatan), dan reflection (refleksi).

Penelitian ini dilaksanakan selama tiga siklus/putaran.Observasi dibagi dalam tiga putaran, yaitu putaran 1,2 , dan 3 , dimana masing putaran dikenai perlakuan yang sama (alur kegiatan yang sama) dan membahas satu sub pokok bahasan yang diakhiri dengan tes formatif di akhir masing putaran. Dibuat dalam tiga putaran dimaksudkan untuk memperbaiki sistem pengajaran yang telah dilaksanakan.

\section{Prosedur Penelitian}

a. TahapPersiapan

Kegiatan yang dilakukan dalam tahap persiapan ini adalah mempersiapkan segala sesuatu yang berhubungan dengan pelaksanaan penelitian. Dalam kegiatan ini diharapkan pelaksanaan penelitian akan berjalan lancer dan mencapai tujuan yang diinginkan. Kegiatan persiapan ini meliputi:(1) kajian pustaka, (2) pengurusan administrasi perijinan, (3) penyusunan rancangan penelitian, (4) orientasi lapangan, dan (5) penyusunan instrumen penelitian.

b. Tahap Pelaksanaan

Pada tahap pelaksanaan penelitian ini, kegiatan yang dilakukan meliputi:(1) pengumpulan data melalui tes dan pengamatan yang dilakukan persiklus, (2) diskusi dengan pengamat untuk memecahkan kekurangan dan kelemahan selama proses belajar mengajar persiklus, (3) menganalisi data hasil penelitian persiklus, (4) menafsirkan hasil analisis data, dan (5) bersama-sama dengan pengamat menentukan langkah perbaikan untuk siklus berikutnya.

c. Tahap Penyelesaian

Dalam tahap penyelesaian, kegiatan yang dilakukan meliputi:(1) menyusun draf laporan penelitian, (2) mendiskusikan draf laporan penelitian, (3) merevisi draf laporan penelitian, (4) menyusun naskah laporan penelitian, dan (5) menggandakan laporan penelitian.

\section{Teknik Analisis Data}

Untuk mengetahui keefektivan suatu metode dalam kegiatan pembelajaran perlu diadakan analisa data. Pada penelitian ini menggunakan teknik analisis deskriptif kualitatif, yaitu suatu metode penelitian yang bersifat menggambarkan kenyataan atau fakta sesuai dengan data yang diperoleh dengan tujuan untuk mengetahui prestasi belajar yang dicapai siswa juga untuk memperoleh respon siswa terhadap kegiatan pembelajaran serta aktivitas siswa selama proses pembelajaran.

Untuk menganalisis tingkat keberhasilan atau persentase keberhasilan siswa setelah proses belajar mengajar setiap putarannya dilakukan dengan cara memberikan evaluasi berupa soal tes tertulis pada setiap akhir putaran. Analisis ini dihitung dengan menggunakan statistik sederhana yaitu:

a. Untuk menilai ulangan atau tes formatif

Peneliti melakukan penjumlahan nilai yang diperoleh siswa, yang selanjutnya dibagi dengan jumlah siswa yang ada di kelas tersebut sehingga diperoleh rata-rata tes formatif dapat dirumuskan:

$$
\bar{X}=\frac{\sum X}{\sum N}
$$


b. Untuk ketuntasan belajar

Ada dua kategori ketuntasan belajar yaitu secara perorangan dan secara klasikal. Berdasarkan petunjuk pelaksanaan belajar mengajar kurikulum 1994 (Depdikbud, 1994), yaitu seorang siswa telah tuntas belajar bila telah mencapai skor $65 \%$ atau nilai 65 , dan kelas disebut tuntas belajar bila di kelas tersebut terdapat $85 \%$ yang telah mencapai daya serap lebih dari atau sama dengan $65 \%$. Untuk menghitung persentase ketuntasan belajar digunakan rumus sebagai berikut:

$$
P=\frac{\sum \text { Siswa..Tuntas }}{\sum \text { Siswa }} \times 100 \%
$$

c. Untuk lembar observasi

1) Lembar observasi pengelolaan metode pemberian balikan.

Untuk menghitung lembar observasi pengelolaan metode pemberian balikan digunakan rumus sebagai berikut:

$$
\bar{X}=\frac{P_{1}+P_{2}}{2}
$$

2) Lembar observasi aktivitas guru dan siswa

Untuk menghitung lembar observasi aktivitas guru dan siswa digunakan rumus sebagai berikut.

$$
L O(\%)=\frac{\bar{X}}{\sum X} \times 100 \%
$$

\section{HASIL DAN PEMBAHASAN}

\section{Siklus I}

a. Tahap Perencanaan

Pada tahap ini peneliti mempersiapkan perangkat pembelajaran yang terdiri dari rencana pelajaran 1, LKS 1 , soal tes formatif 1 dan alat-alat pengajaran yang mendukung. Selain itu juga dipersiapkan lembar observasi pengolahan pembelajaran dengan metode pemberian balikan, dan lembar observasi aktivitas guru dan siswa.

b. Tahap Kegiatan dan Pelaksanaan

Pada akhir proses belajar mengajar siswa diberi tes formatif I dengan tujuan untuk mengetahui tingkat keberhasilan siswa dalam proses belajar mengajar yang telah dilakukan.

Aspek-aspek yang mendapatkan kriteria kurang baik adalah memotivasi siswa, menyampaikan tujuan pembelajaran, pengelolaan waktu, dan siswa antusias. Keempat aspek yang mendapat penilaian kurang baik di atas, merupakan suatu kelemahan yang terjadi pada siklus I. Dan akan dijadikan bahan kajian untuk refleksi dan revisi yang akan dilakukan pada siklus II.
Aktivitas guru yang paling dominan pada siklus I adalah membimbing dan mengamati siswa dalam menemukan konsep yaitu 18,33\%. Aktivitas lain yang persentasenya cukup besar adalah memberi umpan balik/evaluasi/tanya jawab dan menjelaskan materi yang sulit yaitu masing-masing sebesar 15,00\% dan 11,67\%. Sedangkan aktivitas siswa yang paling dominan adalah bekerja dengan sesama anggota kelompok dan mendengarkan/memperhatikan penjelasan guru yaitu 19,92\% dan 18,33\%. Aktivitas lain yang persentasenya cukup besar adalah, diskusi antar siswa/antara siswa dengan guru, dan membaca buku yaitu masing-masing 13,95 dan 12,71\%.

Pada siklus I, secara garis besar kegiatan belajar mengajar pembelajaran dengan metode pemberian balikan sudah dilaksanakan dengan baik, walaupun peran guru masih cukup dominan untuk memberikan penjelasan dan arahan karena model tersebut masih dirasakan baru oleh siswa.

Sehingga dapat dijelaskan bahwa dengan menerapkan pembelajaran dengan metode pemberian balikan diperoleh nilai rata-rata prestasi belajar siswa adalah 66,94 dan ketuntasan belajar mencapai $69,44 \%$ atau ada 25 siswa dari 36 siswa sudah tuntas belajar. Hasil tersebut menunjukkan bahwa pada siklus pertama secara klasikal siswa belum tuntas belajar, karena siswa yang memperoleh nilai $\geq 65$ hanya sebesar $69,44 \%$ lebih kecil dari persentase ketuntasan yang dikehendaki yaitu sebesar 85\%. Hal ini disebabkan karena siswa masih merasa baru dan belum mengerti apa yang dimaksudkan dan digunakan guru dengan menerapkan pembelajaran dengan metode pemberian balikan. Siswa kurang begitu antusias selama pembelajaran berlangsung.

d. Refleksi dan Refisi

1) Guru perlu lebih terampil dalam memotivasi siswa dan lebih jelas dalam menyampaikan tujuan pembelajaran. Dimana siswa diajak untuk terlibat langsung dalam setiap kegiatan yang akan dilakukan.

2) Guru perlu mendistribusikan waktu secara baik dengan menambahkan informasi-informasi yang dirasa perlu dan memberi catatan

3) Guru harus lebih terampil dan bersemangat dalam memotivasi siswa sehingga siswa bisa lebih antusias.

\section{Siklus II}

a. Tahap kegiatan dan pelaksanaan 
Aspek-aspek yang diamati pada kegiatan belajar mengajar (siklus II) yang dilaksanakan oleh guru dengan menerapkan pembelajaran dengan metode pemberian balikan mendapatkan penilaian yang cukup baik dari pengamat. Maksudnya dari seluruh penilaian tidak terdapat nilai kurang. Namum demikian penilaian tersebut belum merupakan hasil yang optimal, untuk itu ada beberapa aspek yang perlu mendapatkan perhatian untuk penyempurnaan penerapan pembelajaran selanjutnya. Aspek-aspek tersebut adalah memotivasi siswa, membimbing siswa merumuskan kesimpulan/ menemukan konsep, dan pengelolaan waktu.

Sedangkan untuk aktivitas siswa yang paling dominan pada siklus II adalah Bekerja dengan sesama anggota kelompok yaitu (21,04\%). Jika dibandingkan dengan siklus I, aktivitas ini mengalami peningkatan. Aktivitas siswa yang mengalami penurunan adalah mendengarkan/memperhatikan penjelasan guru $(17,92 \%)$. Diskusi antar siswa/antara siswa dengan guru $(13,75 \%)$, menulis yang relevan dengan $\mathrm{KBM}(7,71 \%)$ dan merangkum pembelajaran (6,67\%). Adapun aktivitas siswa yang mengalami peningkatan adalah membaca buku $(12,08 \%)$, menyajikan hasil pembelajaran (4,58\%), menanggapi/mengajukan pertanyaan/ide $(5,42 \%)$, dan mengerjakan tes evaluasi $(10,83 \%)$.

Nilai rata-rata prestasi belajar siswa adalah 74,27 dan ketuntasan belajar mencapai 80,56\% atau ada 29 siswa dari 36 siswa sudah tuntas belajar. Hasil ini menunjukkan bahwa pada siklus II ini ketuntasan belajar secara klasikal telah mengalami peningkatan.

b. Refleksi dan Revisi

1) Guru dalam memotivasi siswa hendaknya dapat membuat siswa lebih termotivasi selama proses belajar mengajar berlangsung.

2) Guru harus lebih dekat dengan siswa sehingga tidak ada perasaan takut dalam diri siswa baik untuk mengemukakan pendapat atau bertanya.

3) Guru harus lebih sabar dalam membimbing siswa merumuskan kesimpulan/menemukan konsep.

\section{Siklus III}

a. Tahap kegiatan dan pengamatan

Aspek-aspek yang diamati pada kegiatan belajar mengajar (siklus III) yang dilaksanakan oleh guru dengan menerapkan pembelajaran dengan metode pemberian balikan mendapatkan penilaian cukup baik dari pengamat adalah memotivasi siswa, membimbing siswa merumuskan kesimpulan/menemukan konsep, dan pengelolaan waktu.

Aktivitas siswa yang paling dominan pada siklus III adalah Bekerja dengan sesama anggota kelompok yaitu $(19,17 \%)$ dan mendengarkan/menperhatikan penjelasan guru $(18,75 \%)$, aktivitas yang mengalami peningkatan adalah membaca buku siswa $(14,16 \%)$ dan diskusi antar siswa/antara siswa dengan guru $(14,38 \%)$. Sedangkah

Diperoleh nilai rata-rata tes formatif sebesar 80,86 dan dari 36 siswa yang telah tuntas sebanyak 32 siswa dan 4 siswa belum mencapai ketuntasan belajar. Maka secara klasikal ketuntasan belajar yang telah tercapai sebesar 88,89\% (termasuk kategori tuntas).

b. Refleksi

Pada tahap ini akah dikaji apa yang telah terlaksana dengan baik maupun yang masih kurang baik dalam proses belajar mengajar dengan penerapan pembelajaran dengan metode pemberian balikan. Dari data-data yang telah diperoleh dapat duraikan sebagai berikut:

1) Selama proses belajar mengajar guru telah melaksanakan semua pembelajaran dengan baik. Meskipun ada beberapa aspek yang belum sempurna, tetapi persentase pelaksanaannya untuk masing-masing aspek cukup besar.

2) Berdasarkan data hasil pengamatan diketahui bahwa siswa aktif selama proses belajar berlangsung.

3) Kekurangan pada siklus-siklus sebelumnya sudah mengalami perbaikan dan peningkatan sehingga menjadi lebih baik.

4) Hasil belajar siswa pada siklus III mencapai ketuntasan.

Beberapa hasil temuan dalam penitian ini sebagai berikut:

1. Ketuntasan Hasil belajar Siswa

Melalui hasil penelitian ini menunjukkan bahwa pembelajaran dengan metode pemberian balikan memiliki dampak positif dalam meningkatkan prestasi belajar siswa. Hal ini dapat dilihat dari semakin mantapnya pemahaman siswa terhadap materi yang disampaikan guru (ketuntasan belajar meningkat dari sklus I, II, dan III) yaitu masing-masing 69,44\%, 80,56\%, dan 88,89\%. Pada siklus III 
ketuntasan belajar siswa secara klasikal telah tercapai.

\section{Kemampuan Guru dalam Mengelola Pembelajaran}

Berdasarkan analisis data, diperoleh aktivitas siswa dalam proses pembelajaran dengan metode pemberian balikan dalam setiap siklus mengalami peningkatan. Hal ini berdampak positif terhadap prestasi belajar siswa yaitu dapat ditunjukkan dengan meningkatnya nilai rata-rata siswa pada setiap siklus yang terus mengalami peningkatan.

\section{Aktivitas Guru dan Siswa Dalam Pembelajaran}

Berdasarkan analisis data, diperoleh aktivitas siswa dalam proses pembelajaran fisika pokok bahasan pengukuran (waktu, sudut, luas, volume dan satuannya) pembelajaran dengan metode pemberian balikan yang paling dominan adalah bekerja dengan menggunakan alat/media, mendengarkan/ memperhatikan penjelasan guru, dan diskusi antar siswa/antara siswa dengan guru. Jadi dapat dikatakan bahwa aktivitas siswa dapat dikategorikan aktif.

Sedangkan untuk aktivitas guru selama pembelajaran telah melaksanakan langkahlangkah pembelajaran dengan metode pemberian balikan dengan baik. Hal ini terlihat dari aktivitas guru yang muncul di antaranya aktivitas membimbing dan mengamati siswa dalam mengerjakan kegiatan LKS/menemukan konsep, menjelaskan materi yang sulit, memberi umpan balik/evaluasi/tanya jawab dimana prosentase untuk aktivitas di atas cukup besar.

\section{SIMPULAN DAN SARAN}

Dari hasil kegiatan pembelajaran yang telah dilakukan selama tiga siklus, dan berdasarkan seluruh pembahasan serta analisis yang telah dilakukan dapat disimpulkan sebagai berikut:

1. Pembelajaran pembelajaran dengan metode pemberian balikan memiliki dampak positif dalam meningkatkan prestasi belajar siswa yang ditandai dengan peningkatan ketuntasan belajar siswa dalam setiap siklus, yaitu siklus I $(69,44$, siklus II $(80,56 \%)$, siklus III $(88,89 \%)$.

2. Penerapan pembelajaran dengan metode pemberian balikan mempunyai pengaruh positif, yaitu dapat meningkatkan motivasi belajar siswa yang ditunjukan dengan ratarata jawaban siswa yang menyatakan bahwa siswa tertarik dan berminat pembelajaran dengan metode pemberian balikan sehingga mereka menjadi termotivasi untuk belajar.

Dari hasil penelitian yang diperoleh dari uraian sebelumnya agar proses belajar mengajar matematika lebih efektif dan lebih memberikan hasil yang optimal bagi siswa, makan disampaikan saran sebagai berikut:

1. Untuk melaksanakan pembelajaran dengan metode pemberian balikan memerlukan persiapan yang cukup matang, sehingga guru harus mampu menentukan atau memilih topik yang benar-benar bisa diterapkan pembelajaran dengan metode pemberian balikan dalam proses belajar mengajr sehingga diperoleh hasil yang optimal.

2. Dalam rangka meningkatkan prestasi belajar siswa, guru hendaknya lebih sering melatih siswa dengan berbagai macam metode pembelajaran walau dalam taraf yang sederhana, dimana siswa nantinya dapat menemukan pengetahuan baru, memperoleh konsep dan keterampilan, sehingga siswa berhasil atau mampu memecahkan masalahmasalah yang dihadapinya.

3. Untuk penelitian yang serupa hendaknya dilakukan perbaikan-perbaikan agar diperoleh hasil yang lebih baik.

\section{UCAPAN TERIMA KASIH}

Dengan penuh rasa hormat, saya ucapkan teimakasih kepada:

1. Kepala Dinas Pendidikan Kabupaten Lombok Tengah yang telah memfasilitasi, mengizinkan penulis untk mengadakan penelitian hingga dapat terlaksana dengan baik.

2. Bapak Kepala sekolah yang selalu memberi dukungan sejak awal hingga terlaksananya penelitian ini dengan baik.

3. Rekan-rekan guru yang telah memberi dukungan baik secara moral maupun tindakan langsung dalam pelaksanaan penelitian ini.

\section{REFERENSI}

[1]. Arikunto, Suharsimi. (2001). Dasar-dasar Evaluasi Pendidikan. Jakarta: Bina Aksara

[2]. Arikunto, Suharsimi. (2002). Prosedur Penelitian Suatu Pendekatan Praktek. Jakarta: Rineksa Cipta.

[3]. Combs. Arthur. W. (1984). The Profesional Education of Teachers. Allin and Bacon, Inc. Boston.

[4]. Djamarah, Syaiful Bahri. (2002). Strategi Belajar Mengajar. Jakarta: Rineksa Cipta.

[5]. Mukhlis, Abdul. (2003). Penelitian Tindakan Kelas. Makalah Panitian Pelatihan Penulisan Karya Ilmiah untuk Guru-guru se-Kabupaten Tuban.

[6]. Nur, Moh. (2001). Pemotivasian Siswa untuk Belajar. Surabaya. University Press. Universitas Negeri Surabaya. 
56 | JTAM, Vol. 2, No. 1, April 2018, Hal. 51-56

[7]. Soetomo. (1993). Dasar-dasar Interaksi Belajar Mengajar. Surabaya Usaha Nasional.

[8]. Usman, Uzer. (2001). Menjadi Guru Profesional. Bandung: Remaja Rosdakarya.

[9]. Wetherington. H.C. and W.H. Walt. Burton. (1986). Teknik-teknik Belajar dan Mengajar. (terjemahan) Bandung: Jemmars. 